\title{
DOING CRITICAL MANAGEMENT ACCOUNTING RESEARCH IN EMERGING ECONOMIES
}

\author{
Chandana Alawattage \\ Danture Wickramasinghe ${ }^{2}$ \\ Mathew Tsamenyi ${ }^{3}$ \\ Shazhad Uddin ${ }^{4}$
}

\begin{abstract}
The paper introduces methodological and theoretical premises of critical management accounting research and provides some guidance for researchers. We see critical management accounting research in terms of three overlapping and interrelated'analytical acts'that researchers often perform: contextualising, historicising and theorising. To contextualise, researchers need to establish connections between local, everyday management accounting occurrences and changes taking place in the wider socio-political and cultural spheres. Historicising relates micro-histories to macro-histories. Thus, critical researchers need to locate management accounting technologies in historically-specific social and political contexts, and understand their emergence and reproduction as outcomes of the evolution of political-economic systems. Given the empirical findings are often site-specific and idiosyncratic in critical research, theorisation is important. Although they may be quite interesting in their peculiarity, especially to the local readership in those countries, these findings need to be made interesting for wider consumption. Theorising, in this sense, is a critical act signifying local occurrences by raising and placing them in a higher-order schema of meaning.
\end{abstract}

Keywords: management accounting, social theories, history, politics, epistemology, critical studies.

e-mail: c.g.alawattage@abdn.ac.uk - University of Aberdeen

e-mail: danture.wickramasinghe@glasgow.ac.uk - University of Glasgow

3 e-mail: mtsamenyi@ceibs.edu - University of China European Business School

${ }^{4}$ e-mail: snuddin@essex.ac.uk - University of Essex 


\section{INTRODUCTION}

ver the last two decades, there has been an upsurge of accounting research in emerging economies

$(\mathrm{EEs})^{1}$. This is perhaps due partly to the expansion of accounting $\mathrm{PhD}$ programmes worldwide and partly to the growth of accounting journals sympathetic to accounting research in EEs (Van Helden and Uddin 2016). Financial accounting research has received particular attention (Hopper et al. 2009). While management accounting research on EEs has been growing slowly (Alawattage et al. forthcoming), the critical tradition in management accounting research remain embryonic (Hopper and Bui, 2016), and is particularly neglected in Brazil (see Agrizzi and Sian 2015; Wanderley et al. 2011).

The aim of this paper is to introduce the major theoretical and methodological premises on which the critical research trajectory has been based and to direct the future trajectory of this research. It takes the form of a research note, providing some guidance for emerging critical scholars on EEs in identifying critical management accounting issues, suitable theoretical and methodological stances and emancipatory potential. The paper begins by briefly introducing the notion of 'critical research in management accounting' Three important analytical acts of critical management accounting research are discussed in the three subsequent sections. The final section provides some concluding remarks and practical guidance on conducting research.

\section{CRITICAL MANAGEMENT ACCOUNTING RESEARCH}

Two broad traditions of management accounting research can be articulated: 'mainstream' and 'alternative' (Baxter and Chua 2003). The critical tradition is firmly rooted in the 'alternative' management accounting research paradigm. In contrast to the'mainstream' paradigm, which has flourished and is still considered as the only credible research methodology in North America (Zimmerman 2001), alternative accounting research has found fertile ground in the UK, Australia, New Zealand and Europe. To put it crudely, the alternative management accounting research genre views management accounting as'(non) linear, (un)predictable, (non)controllable, (neither) exclusively technical nor well-behaved' (Baxter and Chua 2003, 106-107). For instance, it does not assume that managers are driven exclusively by concerns for economic efficiency and 'corporate objectives' (Ashraf and Uddin, 2011).

Alternative research in management accounting takes very diverse theoretical perspectives and approaches (Cooper and Hopper 2007). The critical tradition is one of several strands within the alternative' paradigm (Baxter and Chua 2003). There is insufficient space here to elaborate on the ontological differences between the various traditions of alternative management accounting research (for details, see Cunliffe 2003; Hopper et al. 2014). Instead, we focus on one particular tradition to provide a deeper understanding. We see critical management accounting research in terms of three overlapping and interrelated'analytical acts' that researchers often perform: contextualising, historicising and theorising. We do not claim that these analytical acts are exclusive to the critical tradition; nevertheless, the differences perhaps lie in the way that these analytical processes are carried out in the critical tradition. As a practice, 'critical interpretation' involves performing these three analytical acts with a view to providing empirical and/or conceptual insights into management accounting phenomena. We shall discuss these in the following sub-sections with special reference to EEs.

Research on countries in the World Bank's lower to upper middle income bands is used as a demarcating criterion to establish the domain of EEs (Source: http// data.worldbank.org/about/country-classifications). 


\section{CONTEXTUALISING}

In a broad sense, contextualising refers to the act of locating an accounting phenomenon in its relevant cultural, political and institutional setting. The idea of contextualisation is driven by the epistemological principle that accounting phenomena may have different meanings depending on the context in which they are located; therefore, their meaning must be understood and explained in relation to the context within which they are embedded. This makes the universalistic claims of mainstream research about accounting phenomena problematic or partial/restricted. Thus, critical researchers argue, accounting research needs a variety of theoretical, methodological and interpretive schemas capable of relating accounting phenomena to their cultural-political idiosyncrasies.

The concern of most critical management accounting researchers has been to explain how various management accounting technologies (which are inevitably Western due to the colonial, settler colonial and postcolonial histories of EEs) are adopted and adapted in particular organisational settings. Therefore, in the first instance, researchers' attention has been on the micro-setting: the particular set of organisational practices, relations and structures that constitute management accounting in that particular organisational setting and how management accounting is'performed'therein. The act of contextualising begins with these micro-organisational insights because these micro-organisational practices, relations and structures must be contextualised in order to explain why and how they exist and persist.

In contextualising, triangulations of various methodological elements, including unstructured and semi-structured interviews, field observations and archival and other in-house documentary evidence, have been quite popular among researchers. Burawoy's (1998) work on the 'extended case method' is worth mentioning. He deploys the idea of locating everyday life in its'extralocal context ${ }^{2}$. This is useful in articulating how critical management accounting research seeks to establish connections between local, everyday management accounting occurrences and changes taking place in the wider socio-political and cultural spheres. Drawing on previous studies, three types of extralocal connection can be identified, through which changes in local management accounting practices have been explained in the context of EEs: political connections, civic connections and epistemic connections.

Political connections refer to dynamics in the evolution of class structures and political states, and how such changes are implicated in the evolution of management accounting technologies at particular organisational sites. Here, attention is paid to how political institutions such as trade unions, party politics and patronage politics are implicated in management accounting practices. Most early critical management accounting studies on EEs observed empirically how the formal design of accounting and accountability systems, which on the surface were textbook models of budgeting and other systems of rational resource allocation and hierarchical accountability, had been reduced to mere ritualistic and ceremonial practices (Alawattage and Wickramasinghe 2008a; Xu and Uddin 2008; Uddin and Hopper 2001; Uddin and Tsamenyi 2005; Wickramasinghe and Hopper 2005; Wickramasinghe et al. 2004). These studies explained how Western rational-economic and managerial models of management were tried in EEs as a way of mitigating various social issues, including gross economic inefficiencies, bureaucratic inflexibilities, and corruption in large state-owned and privatised enterprises, but that such attempts were complicated and often made ineffective and inefficient by such extralocal institutions such as patronage, neopatromonialism and party politics (Uddin and Hopper 2003). Political connections in 
management accounting have also been viewed from a slightly different but related angle, to observe how an emerging set of management accounting techniques is deployed to manage the institutional apparatus of political states. Rather than exploring how management accounting is hindered by the institutional apparatus of EE polity, here the focus has been on the way management accounting is deployed to enhance the relative efficacy of the state and how such attempts have been hindered by various political processes and structures (Tambulasi 2007).

Civic connections refer to the way in which structural and ideological changes take place in the sphere of civil society. We focus here on how these changes implicate management accounting practices at the organisational level. The last two decades or so have witnessed a significant rise in civil society organisations taking over some of the welfare, developmental, regulatory and entrepreneurial functions that were traditionally carried out by the institutional apparatus of political states and profit-seeking organisations. Most prominent in this regard are non-governmental organisations (NGOs) and microfinance-based organisations in rural economies. Both represent neoliberal attempts to reorganise the accountability structures of civil society, mobilising 'social and cultural capital' to achieve the neoliberal aim of reorganising the social relations of civil society on the basis of market principles and capital accumulation. This social trajectory has reconstructed rural social spaces, such as villages, as 'developmental spaces' to be organised and managed through various technologies of governance and accountability, including management accounting (Alawattage et al. 2014). The microfinance-based development trajectory is interesting for management accounting scholars because accountability is no longer a phenomenon to be understood as enacted through formal channels of organisational relationships; instead, 'micro-accountabilities' (Alawattage et al. 2015), which hold individuals convivially accountable to each other in their local settings, must be recognised as a central tool of social governance under neoliberalism, and as a strong means of integrating EE societies into the global neoliberal economy.

The approach of global civil society and international development funding agencies to the political states of EEs is that the political state is no longer the most efficient and effective medium through which to deliver global development and democracy. Organisational forms of civil society, commonly called NGOs, have now been recognised as an alternative. Consequently, NGOs have become a critical element in the organisation of civil societies. Numerous NGOs operate in every EE across a wide spectrum of activities ranging from microfinance to human rights. As such, their operational and performance management systems, calculative practices and accountability systems have been hot topics for critical management accounting researchers. A key observation here is the'accountability paradox' of NGOs: the dominating presence of narrow, functional, bureaucratic, top-down forms of accountability to meet the informational needs of donor agencies, vis-à-vis a broader, social, civic and bottom-up form of accountability to address the democratic needs of grassroots people whose lives are subject to development (Ahmed and Hopper 2014).

The notion of epistemic connection, in the context of our task, originates from the word 'episteme' coined by Foucault (1972), meaning a total set of relations that unites a set of discursive practices, giving rise to changes in existing epistemological figures, sciences and possibly formalised systems. Epistemic actors such as consultants, management gurus, researchers and scientists avail themselves of the political power of their epistemic centres, including universities, consultancy networks, professional associations, and government and extra-government agencies, to promote their epistemic identities as well as ideologies, practices and systems. Thus, epistemic connections refer to the role played by epistemic organisations (such as consulting firms, international funding agencies, universities and management gurus), 
epistemic actors and epistemic practices in the introduction and diffusion of management accounting technologies to social and economic spaces in EEs.

This is reflected in recent management accounting initiatives. For instance, building on his Harvard connections, Robert Kaplan has become a leading epistemological figure as a result of his (and his colleagues') articulation of the new ideas of $A B C$ and BSC. The epistemic connections have been identified and critiqued by critical accounting studies in EEs. Ashraf and Uddin (2016) have demonstrated how new management accounting initiatives in the public sector created a number of life-threatening situations in Pakistan. Similarly, Ashraf and Uddin (2013) found how a multinational consultant regurgitated 'modern' management accounting ideas in the public sector in Pakistan with severe consequences (see alsoTambulasi 2007; van Helden and Uddin 2016; Xu and Uddin 2008; Wanderley et al. 2011; Alvesson and Empson 2008). Hence, an episteme is not simply an idea forming an epistemology, but a set of discursive practices that gives rise to the popularisation of certain ideas in a given context.

\section{HISTORICISING}

Historicising relates micro-histories to macro-histories: it traces how 'things' have changed in the micro-organisational setting, and then explains them in relation to the 'evolution' of wider socio-political and cultural systems. Taking their cue from this approach, critical researchers locate management accounting technologies in historically-specific social and political contexts, and understand their emergence and reproduction as outcomes of the evolution of political-economic systems.

The significance of 'political-economic history' in explaining the emergence and evolution of management accounting was first popularised by Johnson and Kaplan's (1987) classic, Relevance Lost: The Rise and Fall of Management Accounting. Drawing on transaction cost economics and Chandler (1975)'s historical accounts of American industrial capitalism, they related the emergence and growth of cost and management accounting to the institutional imperatives of social evolution, from feudalism to industrial capitalism, through the invention of factory systems during the Industrial Revolution, and thence to monopoly capitalism through the invention of divisionalised M-form organisations. In Johnson and Kaplan's efficiency-seeking logic, cost and management accounting evolved to resolve the functional problems of lost market information when market-based craft production under feudalism was integrated into capitalist factory systems. While offering alternative interpretations of the evolution of cost and management accounting, Hopper and Armstrong's (1991) Marxist critique and other Foucauldian critiques (e.g. Hoskin and Macve 1986) on Johnson and Kaplan's Relevance Lost reinforce the significance of political-economic history in explaining the emergence of accounting technologies. They all agree that, one way or another, the invention and evolution of cost and management accounting techniques relate to the political-economic imperatives of particular phases of capitalism and modernity.

Periodisation of the historical trajectory is important in establishing why and how management accounting technologies emerge, become popular, and are subsequently problematised. In reading through the Relevance Lost argument, as well as other arguments pertaining to the evolution of capitalism, particular historical episodes in the West, such as liberal and neoliberal capitalism, have given rise to different sets of accountability needs, and hence different sets of calculative technologies. For example, traditional absorption costing was a critical imperative in the early phase of industrial capitalism, and was thus an important management accounting technique for centuries. However, in the neoliberal phase of market capitalism, when market competition had become the most crucial determinant of a firm's 
success or failure and technologically the relative significance of direct costs had declined in relation to the ever-increasing magnitude of overheads, traditional overheads absorption was no longer capable of addressing the competitive needs of flexibility and accuracy. $A B C$ therefore became the state-of-the-art in costing (see Armstrong 2000, 2002). A similar narrative can be built for the popularisation of BSC in terms of the need to balance competing dimensions of financial and non-financial performance measures and link the operations and strategy of organisations (Seal and Ye 2014). Accountability needs, and therefore the invention of calculative practices, are deemed to have arisen from the necessities of particular modes of production that characterise distinct phases of political economic development.

In a similar vein, but with reference to their own peculiar historical trajectories, the reproduction of accounting practices in EEs has also been explained. According to Hopper et al. (2009; see also Alawattage and Wickramasinghe 2008b), EEs have experienced somewhat common political-historical trajectories, from colonial despotism, through post-colonial state capitalism to neoliberal market capitalism. Each phase denotes a specific mode of production (with country-specific differences), and each imposes a different mode of control, and therefore different types of informing technologies.

During the colonial despotism phase, the mode of production was characterised by the dominance of mercantile colonial capital organised into company states, with dominating military power to impose coercive regimes of governance and control on the colonial population. Institutional arrangements were such that the head offices were in the colonial centres, and management agencies managed the operations in the peripheral colonies mainly through despotism. Hence, 'accounting' was largely confined to maintaining relations of production (i.e. relations through which surplus value is appropriated), while management of the labour process (i.e. relations in production) was largely through coercive control based on racial and ethnic differences involving physical violence (see Alawattage and Wickramasinghe 2009; Hopper et al. 2009; Maltby and Tsamenyi, 2010).

Independence then brought state capitalism as an ideal mode of transforming colonial despotism into a more humane, independent and progressive mode of production. The institutional arrangement of capital was based on state-owned enterprises; hence, accounting received more controlling emphasis as an informing technology working across the state bureaucracy. Bureaucratic rational-legal accounting and enterprise budgeting within national central state planning became especially important accounting control devices. Nevertheless, such ideals were not entirely met, as postcolonial politics of patronage, party, and ethnicity and race often took precedence over the bureaucratic rational-legal and accounting logics of managing economic enterprises. As mentioned in the previous section, the outcome was that accounting became rather ceremonial, ritualistic, and irrelevant for internal control (Uddin and Tsamenyi 2005). Accounting was performed only for external legitimation (see Alawattage and Wickramasinghe 2008a; Uddin and Hopper 2001; Wickramasinghe and Hopper 2005; Wickramasinghe et al. 2004).

Decades of failures of state capitalist regimes in many EEs then resulted in 'structural reforms' patronised by global development agencies such as the World Bank, the IMF and the OECD (Tsamenyi et al. 2008; Uddin et al. 2011). This marked a distinct historical phase with a different mode of production, in which capital was reorganised into private ownership through market-driven institutions, including stock exchanges and other regulatory institutions promoting market logics of coordinating economic activities. This gave rise to globalised capital, export zones, stronger capital markets, greater financial regulation and enforcement, and reduced political intervention. Even when ownership was not transferred to the private sector, managerial ideologies and systems were 'modernised' by importing private-sector managerial practices and ideologies into the public sector in the name of new public management. Consequently, in both private- and public-sector organisations in EEs, there was an'accounting signification' in order to 
institutionalise new regimes of market-driven, performance-based management. Accounting started to become more visible and crucial in the day-to-day operations of enterprises, although cultural-political elements such as crony-capitalism, patronage politics and political corruption still played significant roles in reshaping the actual performance of management control systems. Nevertheless, amid all these political missteps, there have been ongoing attempts to import contemporary Western best practices (see van Helden and Uddin 2016).

Micro-organisational ethnographic accounts of management accounting changes very rarely provide opportunities to explain the changes in terms of long-term regime changes in political economic systems or modes of production. Nevertheless, it is important to understand and appreciate historical episodes experienced by a particular nation state, to the extent that the analysis can be confined to the political nature of the particular historical episode to which such ethnographic accounts can be related (Tsamenyi et al. forthcoming; Ashraf and Uddin 2015).

\section{THEORISING}

Theorising refers to the critical act of connecting empirical findings to relevant theoretical frameworks with the aim of (a) 'explaining'local occurrences in terms of theoretical propositions and/or (b) 'illustrating' how certain theoretical propositions are in play at specific empirical sites. There is a certain duality of actions here: using theory as a sense-making device, and using data as a medium to illustrate (or critique) the usefulness of theoretical frameworks. Critical management accounting research on EEs often concentrates on management accounting practices, relationships and structures at specific organisational sites. Consequently, the empirical findings are often site-specific and idiosyncratic. Although they may be quite interesting in their peculiarity, especially to the local readership in those countries, these findings need to be made interesting for wider consumption. This is where the critical act of theorising (and theoretical generalisation) becomes an important element of critical accounting projects. Theorising, in this sense, is a critical act signifying local occurrences by raising and placing them in a higher-order schema of meaning.

Theoretical insights for critical research generally come from 'social theories'. They encompass ideas about how societies and social systems are constituted, how they are organised, controlled and disciplined, how they change and evolve, how individuals interact with social institutions, methods of explaining social behaviour, and systems of social structuration and stratifications such as class, gender and ethnicity. This list is not exhaustive, but essentially social theories provide alternative ways of thinking about social systems and social interactions. They emanate from many disciplinary fields, ranging from neoclassical economics to sociology and political sciences, and hence provide transdisciplinary foundations to explain management accounting occurrences in micro settings by connecting them to wider socio-political dynamics. As such, they enable critical researchers to see the socio-political functionalities of management accounting beyond the techno-managerial rationales that mainstream wisdom often attributes to management accounting techniques. They become analytical tools through which the critical acts of contextualising and historicising discussed above are to be meaningfully carried out.

Drawing on existing research in EEs, we aim to articulate a particular theoretical trajectory within critical traditions with an empirical focus and taking key findings into consideration. This is summarised below in Table 1. 
Table 1: Theoretical trajectories of management accounting practices in EES

\begin{tabular}{|c|c|c|}
\hline Empirical/ analytical focus & Theoretical frameworks drawn on & Key findings/conclusions \\
\hline Theorising political connections & $\begin{array}{l}\text { Development sociology; political } \\
\text { economy (e.g. Marxism and post- } \\
\text { Marxism, including Gramscian } \\
\text { hegemony, Burawoy's factory } \\
\text { regimes, Weberian rationalities }\end{array}$ & $\begin{array}{l}\text { How dialectical connections between polity, society and economy have } \\
\text { played out in the reproduction of management accounting practices in } \\
\text { EEs. } \\
\text { How the co-existence of feudal and capitalist modes of production has } \\
\text { changed the meaning and practices of accounting, creating issues in the } \\
\text { execution of reform programmes. } \\
\text { Significance of extra-organisational political dynamics in shaping and } \\
\text { reshaping management accounting practices }\end{array}$ \\
\hline Theorising epistemic connections & $\begin{array}{l}\text { Eclectic use of post-structural/ } \\
\text { postmodern analyses of } \\
\text { organisational sociology, coupled } \\
\text { with structuration theory, ANT, neo- } \\
\text { institutionalism and postcolonialism. }\end{array}$ & $\begin{array}{l}\text { Since colonialism, the West has always dominated managerial knowledge } \\
\text { construction in the Rest of the World. } \\
\text { Accounting was initially an outcome of the imperial project of colonisation. } \\
\text { Postcolonial hegemony continues with epistemic institutions such as the } \\
\text { World Bank, OECD, Western consulting firms and universities. } \\
\text { Complex epistemic actor networks are being continuously formed and } \\
\text { reformed for the translation of Western managerial knowledge and } \\
\text { practices. } \\
\text { There are interesting paradoxical findings between institutional } \\
\text { isomorphism and convergence on the one hand, and institutional and } \\
\text { cultural heterogeneity on the other. } \\
\text { While the accounting change agenda is inspired by the global function of } \\
\text { ideas development, local ramifications may reconstitute the meaning and } \\
\text { sustainability of these changes. }\end{array}$ \\
\hline Theorising civic connections & $\begin{array}{l}\text { Post-Foucauldian and post- } \\
\text { structural theory of development/ } \\
\text { under-development }\end{array}$ & $\begin{array}{l}\text { Rural social spaces (e.g. villages) have been reconstructed as } \\
\text { 'developmental spaces' to be organised and managed through various } \\
\text { technologies of governance and accountability, including accounting. }\end{array}$ \\
\hline
\end{tabular}

\section{CONCLUDING REMARKS}

This paper has aimed to introduce major theoretical and methodological premises and provide some guidance to emerging critical scholars in EEs and in Brazil. We have identified three important elements of critical management accounting research: contextualising, historicising and theorising.

We argue that a broader understanding is critical to conducting management accounting research in countries such as Brazil. In organisational and developmental policy making, new practices are introducing changes to management accounting controls, governance and forms of accountability. New ideas such as activity-based costing, balanced scorecards, new public management, public-private partnerships, strategic management and the like are at the epicentre of change programmes. The aim of using these ideas in organisations and in policy making is to eliminate resource waste, bottlenecks in processes, struggles in decision making and weaknesses in controls and governance, and to gain strategic advantage. This is understandable from a managerial perspective. However, the actual practices and their consequences may be variable and even surprising. In research, such variable consequences and surprises must be brought into the academic spotlight.

How can we do this? First, we must contextualise and historicise the research object. For several reasons, intensive and longitudinal case studies, as opposed to hypothesis testing methodologies, are very useful for contextualising and historicising. Case studies enable us to focus on particular research sites (an organisation or a moment of policy making) to explore particular circumstances, such as the types of people involved, patterns of doing things, the politics of the work and processes, or glass ceilings that cannot be broken. This helps unpack complex issues through detailed examination of the opinions and expressions of key actors. Clearly, hypothesis tests and statistical inferences are not suited to such unpacking exercises. Intensive studies also lead to the development of interesting, previously untold stories, providing meaningful topics for research publications in top-ranked interpretive and critical accounting journals. In any story, we need to identify an appealing plot, the key actors involved (both human and non-human), and their actions in relation to the implementation/use of a particular management accounting technology in the organisation or policy making in question. Thus, through 
interview scripts, archival materials and ethnographic experiences, the researcher can build in-depth understandings and contribute to ongoing academic debates. Compiling a story of this kind is unthinkable under the purview of hypothesis testing.

Second, we must theorise the research objects so that they can be useful to wider audiences. Table 1 provides a flavour of accounting research employing social theories (for more detail, see Hopper et al. 2014). We do not wish to suggest a particular theory for EE researchers. In fact, theoretical triangulation is a fruitful method of advancing critical management accounting research. Caution must be taken here, given fundamentally differing assumptions between theories and methodologies.

Why use theory or theories? Theorisation makes a story meaningful and explainable. It can also accommodate the context and history in a meaningful analysis of how and why management accounting practices become variable, unintended and surprising. This enables managers, administrators and policy makers to deal with questions such as 'so what?' and 'when then?' in their efforts to 'customise' practices to the local context. Hypothesis tests cannot achieve this because they illuminate items of 'statistical' rather than managerial or policy significance. The advantages of using social theories are not only that they strengthen academic scholarship, but also that they appeal to a broad range of constituencies.

Finally, critical management accounting research is equipped with tools to challenge the claims of absolute truth and offer opportunities for informed and democratic debate. Such research is not about providing technical answers to managers and policy makers, but focusing on processes rather than outputs, providing multiple choices and uncovering hidden agendas. Critical scholarship has the potential to uncover possibilities for individual human beings to escape or initiate change in oppressive accounting practices (Modell forthcoming). This strand of research enables us to identify conditions underlying apparently neutral management accounting technologies. Understanding and critiquing these management accounting technologies is vital to offer opportunities for change and emancipation. Critical researchers equipped with the above analytical acts are in a better position to articulate alternative ways of doing management accounting which are inclusive, sustainable and expansive.

\section{REFERENCES}

Agrizzi, D., and S. Sian. 2015. Artificial corporatism: A portal to power for accountants in Brazil. Critical Perspectives on Accounting 27:56-72.

Ahmed, Z., and T. Hopper. 2014. Politics, development and NGO accountability. In Z. Hoque and L. Parker (eds), Performance Management in Nonprofit Organizations: Global Perspectives. London: Routledge, $17-42$.

Alawattage, C., C. Graham, and D. Wickramasinghe. 2015. Microaccountability and biopolitics: Microfinance in a Sri Lankan village. Paper presented at the Interdisciplinary Perspectives on Accounting Conference, Stockholm, Sweden.

Alawattage, C., and D. Wickramasinghe. 2008a. Appearance of accounting in a political hegemony. Critical Perspectives on Accounting 19 (3):293-339. 
- _ 2008b. Changing regimes of governance in a less developed country. Research in Accounting in Emerging Economies 8:273-310.

2009. Institutionalisation of control and accounting for bonded labour in colonial plantations: A historical analysis. Critical Perspectives on Accounting 20 (6):701-715.

Alawattage, C., D. Wickramasinghe, and A. Tennakoon. 2014. Performing civil society. In Z. Hoque and L. Parker (eds), Performance Management in Nonprofit Organizations: Global Perspectives. London: Routledge, 394-418.

Alawattage, C., D. Wickramasinghe, and S.N. Uddin. Forthcoming. Theorising management accounting practices in less developed countries. In E. Harris (ed.), The Routledge Companion to Performance Management and Control. London: Routledge.

Alvesson, M., and L. Empson. 2008. The construction of organizational identity: Comparative case studies of consulting firms. Scandinavian Journal of Management 24 (1):1-16.

Armstrong, P. 2000. Accounting for insecurity. Critical Perspectives on Accounting 11 (4):383-406.

___ 2002. The costs of activity-based management. Accounting, Organizations and Society 27 (12):99-120.

Ashraf, M.J., and S.Uddin. 2011. Management accounting research in public sector in emerging economies: A critical evaluation. In M. Abdul-Kader and J. Ashraf (eds), Review of Management Accounting Research. London: Palgrave, 415-450.

Ashraf, M.J., and S. Uddin. 2013. A consulting giant; a disgruntled client: A'failed' attempt to change management controls in a public sector organisation. Financial Accountability \& Management 29 (2):186-205.

Ashraf, J., and S. Uddin. 2015. Military, 'managers' and hegemonies of management accounting controls: A critical realist interpretation. Management Accounting Research 29:13-26.

Ashraf, J., and S.N. Uddin. 2016. Regressive consequences of management accounting and control reforms: A case from a less developed country. Critical Perspectives on Accounting 41:18-33.

Baxter, J., and W.F. Chua. 2003. Alternative management accounting research: Whence and whither. Accounting, Organizations and Society 28 (2-3):97-126.

Burawoy, M. 1998. The extended case method. Sociological Theory 16 (1):4-33.

Chandler, Jr., A. D. (1975), The Visible Hand: The Managerial Revolution in American Business. Cambridge, MA: Harvard University Press. 
Cooper, D., and Hopper, T.M. 2007. Critical theorising in management accounting research. In C.S. Chapman, A.G. Hopwood, and M.D. Shields (eds), Handbook of Management Accounting Research. Oxford: Elsevier, 207-245.

Cunliffe, A.L. 2003. Reflexive inquiry in organizational research: Questions and possibilities. Human Relations 56 (8):983-1003.

Foucault, M. 1972. The Archaeology of Knowledge. London: Tavistock Publications.

Hopper, T., J. Ashraf, D. Wickramasinghe, and S.N. Uddin. 2014. Social theorisation of accounting: Challenges to positive research. In S. Jones (ed.), Routledge Companion to Financial Accounting Theory. London: Routledge, 452-471.

Hopper, T., and B. Bui. 2016. Has management accounting research been critical? Management Accounting Research, 31:10-30.

Hopper, T., M. Tsamenyi, S. Uddin, and D. Wickramasinghe. 2009. Management accounting in less developed countries: What is known and needs knowing. Accounting, Auditing \& Accountability Journal $22(3): 469-514$.

Hoskin, K.W., and R.H. Macve. 1986. Accounting and the examination: A genealogy of disciplinary power. Accounting, Organizations and Society 11 (2):105-136.

Johnson, H.T., and R.S. Kaplan. 1987. Relevance Lost : The Rise and Fall of Management Accounting. Boston, MA: Harvard Business School Press.

Maltby, J., and M. Tsamenyi. 2010. Narrative accounting disclosure: Its role in the gold mining industry on the Gold Coast 1900-1949. Critical Perspectives on Accounting 21 (5):390-401.

Modell, S. Forthcoming. Critical realist accounting research: In search of its emancipatory potential. Critical Perspectives on Accounting, doi:10.1016/j.cpa.2016.03.001.

Seal, W., and L. Ye. 2014. The balanced scorecard and the construction of a management control discourse. Journal of Accounting \& Organizational Change 10 (4):466-485.

Tambulasi, R.I.C. 2007. Who is fooling who? New public management-oriented management accounting and political control in Malawi's local governance. Journal of Accounting \& Organizational Change 3 (3):302-328.

Tsamenyi , M., T.M. Hopper, and S.N. Uddin. Forthcoming. Management accounting in a gold mining company in Ghana. Journal of Accounting \& Organizational Change.

Tsamenyi, M., J.M. Onumah, and E. Tetteh-Kumah. 2008. Post-privatization performance and organizational changes: Case studies from Ghana. Critical Perspectives on Accounting 21 (5):428-442. 
Uddin, S., B. Gumb, and S. Kasumba. 2011. Trying to operationalise typologies of the spectacle: A literature review and a case study. Accounting Auditing and Accountability Journal 24 (3):288-315.

Uddin, S., and T. Hopper. 2001. A Bangladesh soap opera: Privatisation, accounting, and regimes of control in a less developed country. Accounting,Organizations and Society 26 (7-8):643-672.

——_. 2003. Accounting for privatisation in Bangladesh:Testing World Bank claims. Critical Perspectives on Accounting 14 (7):739-774.

Uddin, S., and M. Tsamenyi. 2005. Public sector reforms and the public interest: A case study of accounting control changes and performance monitoring in a Ghanaian state-owned enterprise. Accounting, Auditing \& Accountability Journal 18 (5):648-674.

Van Helden, J., and S. Uddin. 2016. Public sector management accounting in emerging economies: A literature review. Critical Perspectives on Accounting 41:34-62.

Wanderley C, J. Cullen, and M. Tsamenyi. 2011. Privatisation and electricity reforms in Brazil: Accounting perspective. Journal of Accounting in Emerging Economies, 1:53-75.

Wickramasinghe, D., and T. Hopper. 2005. A cultural political economy of management accounting controls: A case study of a textile mill in a traditional Sinhalese village. Critical Perspectives on Accounting 16 (4):473-503.

Wickramasinghe, D., T. Hopper, and C. Rathnasiri. 2004. Japanese cost management meets Sri Lankan politics: Disappearance and reappearance of bureaucratic management controls in a privatised utility. Accounting, Auditing \& Accountability Journal 17 (1):85-120.

Xu, W., and S. Uddin. 2008. Public sector reforms, privatisation and regimes of control in a Chinese enterprise. Accounting Forum 32 (2):162-177.

Zimmerman, J.L. 2001. Conjectures regarding empirical managerial accounting research. Journal of Accounting and Economics 32 (1-3):411-427. 